\title{
Pamiętnik
}

\section{Heleny Wróblewskiej, \\ mieszkanki \\ Ziem Zachodnich}

opracowanie:

\section{JAKUB ISAŃSKI}

Instytut Socjologii

Uniwersytet im. Adama Mickiewicza w Poznaniu

DOI: https://doi.org/10.26774/rzz.186

$01 / 2017$

\section{ROCZNIK}

\section{ZIEM}

\section{ZACHODNICH}

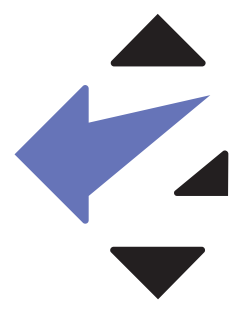


Pamiętnik ${ }^{1}$ został napisany przez Helenę Wróblewską, nauczycielkę osiadłą w Drawsku Pomorskim, pochodzącą prawdopodobnie z terenów dzisiejszej Białorusi, z pamiętnika bowiem dowiadujemy się jedynie, że pierwszą stacją kolejową, przez którą przybyła ona wraz z rodziną na zachód, jest Hajnówka. Autorka przybyła na Ziemie Zachodnie i Północne w maju 1946 r., kierując się do Drawska Szczecińskiego, gdzie wcześniej osiedliła się jej matka. Rękopis liczy 18 stron, opisywane są w nim losy autorki do roku 1970.

\section{Osadnictwo i szaber}

Czytając pamiętniki z czasów powojennych, nie można zapominać, że zakończenie wojny w maju 1945 r. nie oznaczało w wielu przypadkach zakończenia działań wojennych. Co najmniej do ogłoszonej w 1947 r. amnestii na terenie Polski działały zbrojne oddziały podziemia niepodległościowego. Stacjonowały tu również znaczne oddziały Armii Radzieckiej (w tym oddziały NKWD²). Czynnikiem destabilizującym życie społeczne były także zorganizowane działania szabrownicze, którymi zajmowali się po wojnie przedstawiciele wszystkich nacji, stanów i zawodów. Rozmontowywano więc i wywożono do ZSRR istniejące fabryki i ocalałą infrastrukturę. Przy tej okazji bezpowrotnie zniszczono ogromną ilość nadających się do użycia sprzętów, maszyn, a także szlaki kolejowe ${ }^{3}$. Grabież i dewastacja na wiele lat po wojnie zahamowały możliwości gospodarczego uruchomienia ocalałych zakładów i wykorzystania surowców. Mniej lub bardziej zorganizowany był także szaber prywatny, z początku rozumiany jako naturalna sprawiedliwość dziejowa, zamieszkiwanie w domach i gospodarstwach opuszczanych przez Niemców i używanie ich wyposażenia, by następnie przybrać postać społecznej plagi, działań realizowanych przez

1 Prezentowany materiał pochodzi z korpusu 1100 pamiętników nadsyłanych do Instytutu Zachodniego w Poznaniu w ramach konkursów ogłaszanych w latach 1956-1970. Ich treść była dotąd, fragmentarycznie, wykorzystywana w wielu publikacjach naukowych, zob. m.in.: Pamiętniki osadników ziem odzyskanych, oprac. Z. Dulczewski, A. Kwilecki, Poznań 1963; A. Kwilecki, Z pogranicza socjologii $i$ historii. Elementy warsztatu badawczego, Poznań 2016; Podpatrywanie miasta. Miasto w socjologii poznańskiej 1920-2000, red. S. Lisiecki, J. Kubera, Poznań 2016. Niniejszy tekst przedstawia opracowanie treści wybranego pamiętnika pod kątem zmieniających się warunków życia społecznego osadników w powojennej Polsce. Przedstawiany pamietnik, opatrzony numerem ewidencyjnym P552-234, nadesłany został na konkurs ogłoszony w 1970 r. W cytowanych fragmentach zachowano pisownię oryginalną. Pamiętnik jest przykładem zapisu wspomnień zbieranych stosowaną w socjologii metodą autobiograficzna. Autor wysyłał spisane przez samego siebie wspomnienia w odpowiedzi na konkurs zatytułowany „Pamiętnik osadnika Ziem Odzyskanych”. Cały tekst pamiętnika dostępny jest w Archiwum Ziem Zachodnich i Północnych Instytutu Zachodniego im. Zygmunta Wojciechowskiego w Poznaniu.

2 Oddziały Armii Radzieckiej stacjonowały na terenie Polski od czasów wkroczenia na te ziemie w walkach z oddziałami niemieckimi (wówczas jeszcze jako oddziały Armii Czerwonej). Dokładna ich liczbe ustalono dopiero w 1956 r. na ok. 66 tys. żołnierzy, których status regulowała umowa zawarta naonczas pomiędzy rządami PRL i ZSRR. Zarówno liczebność tych oddziałów, jak i status znajdowały się poza wpływem władz polskich, zob. C. Osękowski, Specyfika „Ziem Odzyskanych” po II wojnie światowej. Analiza problemu [w:] „Ziemie Odzyskane” po drugiej wojnie światowej, red. C. Osękowski, G. Strauchold, Zielona Góra 2015 s. 7-19.

3 Stopień dewastacji na „Ziemiach Odzyskanych” - oszacowany w przybliżeniu - wynosił: zniszczenie 45\% izb mieszkalnych, 77\% linii kolejowych, 70\% mostów, 25\% dróg kołowych oraz 80-90\% inwentarza żywego. Dane przytaczam za: R. Skrobelski, Specyfika polityki gospodarczej państwa na „Ziemiach Odzyskanych” w latach 1945-1970, [w:] „Ziemie Odzyskane” po drugiej wojnie..., s. 45-58. Jak podaje C. Osękowski (op. cit., s. 8), aż 38 mostów na Odrze zniszczonych w czasie działań wojennych nie zostało odbudowanych do $1989 \mathrm{r}$. 
grupy przestępcze kradnące i dewastujące nie tylko czyjeś mienie, ale i obrabowujące osadników z przywożonego przez nich skromnego majątku. Szabrowali także przybywający na te tereny osadnicy w sytuacji, gdy alternatywą było żebractwo lub śmierć głodowa. Żebrały natomiast, na przykład, siostry zakonne prowadzące zakład opieki nad sierotami wojennymi ${ }^{4}$, który był regularnie okradany przez żołnierzy. Stan zawieszenia i tymczasowości - opisywany w socjologii jako anomia, czyli zanik istniejących norm społecznych regulujących codzienne życie ludzi - pogłębiała także niepewność ostatecznej przynależności państwowej Ziem Zachodnich i Północnych. Osiedleniom Polaków towarzyszyły wysiedlenia Niemców i częste przemieszczanie się osób poszukujących lepszych warunków codziennej egzystencji, ocalałych z wojny członków swoich rodzin lub też chociażby bezpieczeństwa od szerzącego się w pierwszych powojennych latach bezprawia.

Trudno o jednolitą definicję szabru i szabrowników, wydaje się, że był to jeden z codziennych elementów życia społecznego tamtych czasów. Początkowo oznaczał głównie zajmowanie opuszczonych gospodarstw z ich wyposażeniem, z czasem stał się także sposobem na poprawę własnej sytuacji materialnej. Szaber mógł mieć postaci mniej i bardziej zorganizowane, można było zarówno szabrować, jak i być oszabrowanym. W jednej z publikacji o powojennych przesiedleniach, autorzy przedstawiają ów stan następująco:

Plagą dla wyznawców religii menonickiej, którym nie udało się ewakuować, byli najpierw sowieccy, a potem niekiedy i polscy żołnierze. Zabierali oni konie, bydło, świnie, drób, ale także rekwirowali sprzęt domowy. Po nich zjawili się szabrownicy, rekrutujący się z wiejskiej biedoty i małorolnych chłopów. Osiemnastoletnia wówczas Edna Schroeder wspominała: „Straciliśmy wszystko. Mama tłumaczyła nam - nie przejmujcie się. Mama w czasie I wojny światowej straciła wszystko co miała, ale przeżyła. Mama mówiła nam: zachowajcie spokój, bądźcie cicho, dajcie im zabrać co tylko chcą. Do momentu dopóki nie będą nas krzywdzić, wszystko będzie w porządku"5.

Autorka przedstawianego dalej pamiętnika pisze więc w swoich wspomnieniach: „meble, które już zdążyłam kupić u żołnierzy”; i chociaż nie wynika z tego fragmentu, jakiej narodowości byli żołnierze, bez wątpienia można założyć, że posiadane przez nich meble pochodziły z grabieży, a zarobione w ten sposób pieniądze były zapewne rozdzielane pomiędzy uprawiających ten proceder. Wyszabrowany majątek służył nie tylko do poprawy wyposażenia miejsca zamieszkania w dobra materialne, ale także, a może przede wszystkim, jako źródło zarobku, trafiając następnie do sprzedaży w oddalone miejsca, często na tzw. „szaberplacach”.

4 M. Krupecka, Żeńskie wspólnoty zakonne na Środkowym Nadodrzu w latach 1945-1956, [w:] Władze wobec Kościołów i zwiqzków wyznaniowych na Środkowym Nadodrzu w latach 1945-1956, red. E. Wojcieszyk, Poznań 2012, s. 182. 
Czynnikiem utrudniającym ekonomiczną adaptację były także materialne straty wojenne. Dla wielu ludzi oznaczały one utratę całego majątku rodzinnego, co pozostawiało ich na utrzymaniu funkcjonujących agend Państwowego Urzędu Repatriacyjnego, pomocy UNRRA ${ }^{6}$ lub też czyniło niejako naturalnym $w$ tej sytuacji szaber w miejscach, w których się osiedlali. Naturalną w tych warunkach walutą była wódka, o jej wartości pisze we wspomnieniach jeden z autorów: „Za wódkę można było kupić u rosyjskich żołnierzy konia, który kosztował około 3 litry spirytusu"7.

\section{Migracje i osiedlanie się}

Wielka wędrówka Polaków, najpierw na zachód, wraz z przesuwającą się linią frontu, a później na „Ziemie Odzyskane”, rozpoczęła się już w 1944 r. Od 1945 r. organizowały ją Urzędy Repatriacyjne - centralny oraz jego wojewódzkie i powiatowe oddziały. Między listopadem 1945 a styczniem 1949 r. działało także Ministerstwo Ziem Odzyskanych, koordynujące działania na tym obszarze. Przesiedlanie odbywało się według „pasów równoleżnikowych (wschód-zachód), a więc na tereny o zbliżonych warunkach klimatycznych i krajobrazowych"8, a w obszarach przygranicznych osiedlano także zdemobilizowanych żołnierzy. Do 1948 r. do Polski trafiło w ten sposób z ziem wcielonych do ZSRR ${ }^{9}$ ponad 1,5 mln ludzi, a w latach 1955-1960 kolejne 260 tys., zasiedlając tereny zachodniej i północnej Polski. Dodatkowo na ziemie te przybywali w pierwszych latach powojennych także Polacy powracający z Zachodu - z przymusowych przesiedleń, robót, obozów i wreszcie z Polskich Sił Zbrojnych na Zachodzie, a także członkowie polskich organizacji niepodległościowych poszukujący możliwości ukrycia się przed państwowym aparatem represji. Należy pamiętać, że zwłaszcza w pierwszych latach powojennych osiedlaniu się Polaków towarzyszyło równoczesne wysiedlanie Niemców i często dochodziło do przypadków,

6 UNRRA (United Nations Relief and Rehabilitation Administration) - organizacja powołana do niesienia pomocy mieszkańcom krajów zniszczonych podczas działań wojennych. Działała w latach 19431948. Należało do niej ponad 40 krajów przeznaczajacych na pomoc 1\% swojego PKB, jednak aż $94 \%$ pomocy zapewniły trzy kraje: Stany Zjednoczone, Wielka Brytania i Kanada. Warto także wspomnieć, że 75\% udzielonej pomocy docierało do beneficjentów „w naturze”, tj. w postaci ziarna, żywności i zwierząt hodowlanych, co w pierwszych latach powojennych uratowało wielu z nich od głodu, por. K. Kowalski, Plan Marshalla. Uwarunkowania i skutki gospodarczo-polityczne, Łódź 2014.

$7 \quad$ H. Lech, Zatrzymane w pamięci, [w:] Losy Polaków wysiedlonych z Kresów Wschodnich II RP. Przyjazd na Ziemie Zachodnie (1944-1945) w zapiskach wspomnieniowych 40 lat później, red. B.K. Kubis, Opole 2011, s. 157.

8 B. Jancz-Kostuch, Wprowadzenie, [w:] Co kryły walizki „repatriantów”? Informator wystawy. Muzeum Etnograficzne w Poznaniu, kwiecień-wrzesień 2000, Poznań [2000], s. 6. Szerzej pisał o tym także A. Kwilecki, op. cit.

9 Z wielu względów trudno jest ustalić dokładną liczbę Polaków, którzy w 1945 r. znaleźli się poza nowymi granicami Polski, szczególnie na ziemiach wcielonych do ZSRR. Autorzy zajmujący się tymi zagadnieniami wskazują m.in. na to, iż wysiedlenia Polaków z ZSRR rozpoczęły się już przed II wojną światowa, cześci obywateli II RP odmawiano po 1945 r. prawa do wyjazdu do Polski, wielu wreszcie wywodziło się z rodzin o różnym pochodzeniu etnicznym. Należy także pamiętać o ogromnej skali ofiar wojennych wśród ludności cywilnej, zob. o tych kwestiach np. S. Jankowiak, Przemiany narodowościowe na "Ziemiach Odzyskanych" po II wojnie światowej, [w:] "Ziemie Odzyskane” po drugiej wojnie..., s. 33-44. Por. też: Bezdomna Europa. Migracje po II wojnie światowej we współczesnych badaniach humanistów. Zbiór studiów, red. B. Kromolicka, H. Walczak, Szczecin 2015. 
w których w jednym domu zamieszkiwali, przynajmniej na jakiś czas, jego dotychczasowi właściciele oraz nowi przybysze ${ }^{10}$.

Warunki, w jakich dochodziło do osiedlania się nowych przybyszów, były także przyczyną konfliktów pomiędzy nimi. W jednej z opublikowanych relacji z tamtych czasów autorka tak przybliża sytuację osadników przybywających do Polski po 1956 r.:

Nasz dom, gdzie umieszczono około 70 rodzin ze Wschodu, nazywano „ambasadą radziecką" i wytykano palcami. Opowiadano niestworzone historie o tym, jak nie umiemy znaleźć się w cywilizowanym świecie hodując w łazienkach kury i inny inwentarz. Tyle upokorzeń, tyle wstydu! Długie lata żyliśmy we własnym świecie. [...] Jednak pewnego dnia zniknęła siatka i powoli zaczęliśmy się wtapiać w tę, jakże inną od wyobrażeń, ojczyznę. To wtapianie dotyczy głównie pokolenia urodzonych po wojnie. Ludziom starszym było znacznie trudniej. Nigdy nie pozbyli się zaśpiewu w mowie, nigdy nie zapomnieli tego, co było tam, nie umieli wejść całkowicie i do końca w nową rzeczywistość ${ }^{11}$.

Wzajemne animozje i uprzedzenia skutecznie hamowały powstawanie nowych społeczności, umożliwiając pełniejsze rozwinięcie tego procesu dopiero w drugim pokoleniu. Z perspektywy lat można jeszcze dodać, że ceną za włączenie w nurt przemian społeczno-ekonomicznych było zapomnienie o rodzinnych korzeniach, ale wydaje się, że stan ten dotyczył en masse Polaków, którzy zmuszeni byli do życia w powojennej Polsce. Z perspektywy lat można dodać, że wedle danych zebranych w 2012 r. przez ankieterów CBOS 15\% Polaków przyznaje się do „kresowych korzeni", przy czym odpowiedzi takiej udziela aż 51\% mieszkańców województwa lubuskiego, $47 \%$ dolnośląskiego oraz $25 \%$ zachodniopomorskiego ${ }^{12}$.

Trudno dzisiaj ocenić, czy istniejące w latach powojennych przymus i poczucie zagrożenia przyspieszały czy utrudniały integrację z nowym miejscem zamieszkania. Chociaż bowiem z jednej strony, jak wspominam wyżej, pierwsze miesiące od osiedlenia upływały w atmosferze podobnej do czasów wojennych, to z drugiej zamieszkanie w nowym miejscu i pozbawienie zdecydowanej większości materialnych pamiątek, w tym fotografii i aparatów fotograficznych (jak pisze wspomniana wyżej autorka, osoby wyjeżdżające z Kresów obowiązywał zakaz zabierania ze sobą posiadanych aparatów fotograficznych), a także przedmiotów codziennego użytku, sprzyjało integracji z nowym miejscem. Pewien wyjątek stanowiły maszyny i narzędzia przywożone ze sobą przez rzemieślników, jednak wielu z nich dość szybko przekonywało się

10 Ucieczka Niemców przed zbliżającymi się oddziałami radzieckimi, następnie niezorganizowane wysiedlenia i wreszcie zorganizowana akcja przesiedleńcza trwały jeszcze kilka lat po zakończeniu działań wojennych, co sprzyjało utrzymywaniu się stanu tymczasowości i zawieszenia, por. np. G. Strauchold, Jak „Szwaby” (tzw. autochtoni) i „Ukraińcy” (tzw. repatrianci) układali niespodziewane wspólne życie na byłych niemieckich ziemiach wschodnich od 1945 roku, [w:] Bezdomna Europa..., s. 69-80; Niemcy jako problem międzynarodowy po II wojnie światowej, red. S. Sierpowski, Poznań 2010.

11 W. Blacharska, Co to znaczy być „repatriantem”?, [w:] Co kryły walizki..., s. 11-15.

12 M. Herrmann, Kresowe korzenie Polaków, Centrum Badania Opinii Społecznej. Komunikat z badań kwiecień 2012 r. (BS/50/2012), http://www.cbos.pl/SPISKOM.POL/2012/K_050_12.PDF (dostęp: 31 VII 2017 r.). 
w nowym miejscu zamieszkania, że dostępne są tutaj nowsze i technologicznie bardziej zaawansowane odpowiedniki, chociaż ich uruchamianie i stosowanie napotykało szereg przeszkód - od problemów z dopływem energii elektrycznej, poprzez brak części zamiennych, aż do nieumiejętności ich obsługiwania.

\section{Powstawanie nowych wspólnot}

Niezmiernie ciekawym zagadnieniem jest proces stopniowego powstawania wspólnot lokalnych złożonych z osób przybyłych z różnych stron na Ziemie Zachodnie i Północne. Lista czynników utrudniających nawiązywanie więzi jest bardzo długa, a umieścić na niej można: pochodzenie $\mathrm{z}$ odległych od siebie stron, różnice $\mathrm{w}$ wyznawanej religii, mowie, zwyczajach itp. ${ }^{13}$ Do tego dochodziły traumatyczne przeżycia wojenne oraz poczucie zagrożenia utrzymujące się po zakończeniu działań wojennych, a nawiązywaniu więzi nie sprzyjało także powszechne szabrownictwo. Stacjonowały tam również oddziały Armii Czerwonej, w tym specjalne oddziały trofiejne, zajmujące się demontażem i wywozem do ZSRR fabryk, zakładów przemysłowych oraz wszelkiej infrastruktury uznanej za zdobyczną.

Autorka pamiętnika wspomina proces powstawania wspólnoty wśród ludzi przybyłych na te ziemie, w jej opisach widać wiele określeń, które są wymownym świadectwem czasów, w których powstał tekst. Obszary, z których przybywali osadnicy, całe Kresy Wschodnie II RP określane są zbiorczą nazwą „zza Buga”, tutaj z dopełnieniami typu „z południa” oraz „z północy”, natomiast ludzie pochodzący stamtąd jako „Zabugowcy”14. Przesiedlenie Ukraińców w ramach akcji „Wisła” określane jest podobnie, zgodnie z ideologiczną linią oficjalnego języka tamtych czasów, jako „akcja «W»". Dalej autorka pisze o „bandach banderowców”, mając na myśli oddziały Ukraińskiej Armii Powstańczej (UPA). Co ciekawe, we wspomnianym fragmencie jest też mowa o członkach armii Andersa, nieczęsto pojawiających się w publikowanych w Polsce wspomnieniach z tamtych czasów.

Nowe społeczeństwo powstawało w warunkach etnicznej odmienności przypominającej dziedzictwo II RP, wzbogaconej dodatkowo przez sześć lat wojennej traumy, której główny ciężar poniosła ludność cywilna. Dodatkowo, wielu z nich było po wielotygodniowej podróży, często poprzedzonej opuszczeniem ziemi rodzinnej i rozdzieleniem z pozostałymi członkami rodziny. Z zamieszczanych w pamiętnikach relacji można się dowiedzieć, że szczególnie osadnicy przybywający z Kresów Wschodnich traktowani byli jako gorsi, cywilizacyjnie zapóźnieni. Wspomnienia samej podróży dla wielu osadników były przedłużeniem ich wojennej udręki. Z kolei podróż pozostałych członków rodziny autorki przebiegała w znacznie trudniejszych warunkach - infrastrukturalne braki, trudne warunki pogodowe oraz panujący bandytyzm został zapamiętany i opisany na kartach pamiętnika. 
Ze wspomnień autorki wyłania się obraz migracji i osiedlania się jako obfitującego w grabieże i trudy, a po przybyciu na nowe miejsce całymi miesiącami utrzymują się waśnie o etnicznym podłożu, poczucie tymczasowości i obawy przed powrotem Niemców. Powstające w tych warunkach nowe społeczeństwo skupione jest wokół zatroskania o własne bezpieczeństwo (autorka pamiętnika pisze o przypadkowo odkrytym w futerale na okulary zdjęciu sąsiadek, młodych Niemek w mundurach Hitlerjugend). Dopiero nowe pokolenie na „Ziemiach Odzyskanych” miało szansę na życie w warunkach postępującej stabilności opartej na identyfikacji z miejscem urodzenia i stałego zamieszkania. Trudy codziennego życia przesłaniały stopniowo animozje i konflikty, jakimi żyło pokolenie ich rodziców, przyczyniając się do powstawania nowych lokalnych społeczności.

Dalsze losy autorki - zawodowa kariera, następnie rozwód z mężem (spowodowany nadużywaniem przez niego alkoholu) oraz ekonomiczna niezależność - stanowią opis losów osoby, która dobrze zaadaptowała się do warunków życia społecznego ówczesnej Polski. Opisywane przez nią detale życia zawodowego, osiągane sukcesy oraz wysiłek wkładany w zdobywanie kolejnych kwalifikacji, przedstawiane są jako okupione ogromnym wysiłkiem i uporem. Wśród sukcesów, jakimi chwali się autorka, wymienia także zdobycie wyższego wykształcenia prawniczego przez syna, którego po rozwodzie wychowywała bez pomocy męża.

\section{Podsumowanie}

Trudno wyobrazić sobie dzisiaj, jak wiele wyzwań stało przed ludźmi o tak zróżnicowanym pochodzeniu, których codzienne życie musiało toczyć się w warunkach społecznej nieufności i obawy o własne bezpieczeństwo. Taka postawa po sześciu latach wojny była czymś oczywistym, a i pierwsze lata powojenne nie przynosiły wcale poprawy poczucia bezpieczeństwa. Przybywający osadnicy musieli często rozpoczynać gospodarowanie od pochowania zwłok zabitych żołnierzy i cywilów, jakie znajdowali na swoich nowych ziemiach, musieli uważać na miny i pozostawioną broń oraz amunicję czy też wreszcie obserwować kontynuowany na wielu obszarach Polski zbrojny opór podziemia niepodległościowego przeciwko narzucanym siłą nowym porządkom. Wydaje się, że w tej sytuacji wzajemna nieufność i podejrzliwość były nawet bardziej uzasadnione niż otwartość i skłonność do nawiązywania nowych relacji społecznych.

Autorka wspomnień opisuje różne wydarzenia swojego życia, zarówno powojenne przesiedlenie i próby zadomowienia się w nowym miejscu, jak i rozwód z mężem alkoholikiem, oraz kolejne próby usamodzielnienia się razem $\mathrm{z}$ dzieckiem pozostającym na jej utrzymaniu. Przedstawia także drogę swojego zawodowego i społecznego awansu - pracę w księgowości, podejmowane różne inicjatywy społeczne (zakładanie świetlic dla młodzieży, organizowanie wypoczynku letniego), której niejako uwieńczeniem było ukończenie studiów polonistycznych na Uniwersytecie Warszawskim i podjęcie pracy nauczycielki w rodzinnym mieście. Co charakterystyczne dla tamtych czasów, jedną z największych przeszkód w realizacji każdego z tych etapów jest zależność od rozmaitych relacji z innymi ludźmi, od męża w nieudanym małżeństwie, do kolejnych szefów w pracy, którzy próbują blokować autorce pamiętnika możliwości 
rozwoju i, w rezultacie, awansu. Autorka opisuje także swoje zmagania z przeszkodami instytucjonalnymi, które utrudniają jej realizację pomysłów, np. organizację kolejnych świetlic dla młodzieży. Ostatecznie jednak podsumowuje ona swoje życie jako udane, ostatnie wzmianki w pamiętniku pisze już jako osoba o uznanej w społeczności lokalnej pozycji, właścicielka trzypokojowego mieszkania i osoba o poczuciu osobistego sukcesu na miarę czasów, w których przyszło jej żyć.

\section{Helena Wróblewska}

\section{Pamiętnik mieszkanki Ziem Zachodnich}

... Nie pojedziesz do Polski... Nie pojedziesz do Polski... Nie pojedziesz... Otaczają mnie wokół jakieś monstra o groźnych, z dzikim błyskiem pałających oczach, wyciągają kosmate łapy i już, już dosięgają zakrzywionymi szponami. Chcę uciekać, ale nogi ciężkie, jakby wrosły w ziemię, więc tylko mocno przyciskam dziecko do piersi i dysząc ciężko z przerażenia, zasłaniam oczy, by nie widzieć, jak się na mnie rzucą. Ale tylko dalej słyszę groźne głosy, otaczają mnie zewsząd i jak uderzenia ciężkiego młota spadają, przytłaczają, przygniatają zda się do ziemi: nie pojedziesz... nie pojedziesz... nie pojedziesz i nagle zdaję sobie sprawę, że te słowa układają się w jakiś rytm jednostajny i miarowy. Oddycham z ulgą, bo naraz uświadamiam, że to koła pociągu postukują rytmicznie: stuk, stuk, stuk... stuk, stuk, stuk... Ach, więc to tylko koszmarny sen. Budzę się cała spocona pod wrażeniem tego okropnego snu, który jest echem niedawnych przeżyć i kłopotów związanych z załatwianiem formalności repatriacyjnych. Ale już to wszystko mam poza sobą. Już jedziemy. Już nikt nie zawróci mnie z drogi do kraju, do swoich. Uspokojona zasypiam ponownie.

Budzę się późno. Do wagonu przez uchylone drzwi zagląda majowe słońce. Stoimy na jakiejś stacji. Wyglądam ciekawie na zewnątrz wagonu. O Boże! Polski napis! A więc już przekroczyliśmy granicę. Już jesteśmy w kraju. Stacja czyściutka. Oszałamiająco pachną czeremchy. Ludzie chodzą odświętnie ubrani, bo to niedziela. I rozmawiają po polsku! Po polsku, po naszemu! O ukochana, umiłowana, najdroższa, najpiękniejsza mowo ojczysta! Nareszcie słyszę ją wokół siebie jawną i śmiałą, a nie ściszoną, kryjącą się, przytłoczoną obcym językiem. Łzy wzruszenia i radości napływają do oczu. Radość, ogromna niewypowiedziana radość. Nareszcie jestem w kraju, wśród swoich. Mąż przyniósł skądś białego chleba, którego nie widziałam przez pięć lat wojny i okupacji.

Wsiadamy do wagonu i znów jedziemy. Nie bardzo orientujemy się, gdzie nas wiozą, ale niech tam inni za nas się martwią. Trochę dziwimy się, że wpierw mijamy Hajnówkę, a potem Białystok, ale wkrótce wyjaśnia się, że nasz pociąg posyłają tam, gdzie jest wolny tor. Niech sobie wiozą. Jedziemy już tydzień. Pewnego dnia mijamy Warszawę. Z dworca na Pradze widzimy las sterczących ku niebu kikutów murów, same ruiny, ale w tych ruinach tętni życie. Dzwonią tramwaje, kursują taksówki i samochody ciężarowe, ludzie zaaferowani swoimi sprawami dokądś śpieszą, gdzieś podążają. Ten ruch, życie odbiera ruinom ich cmentarną wymowę, nie pozwala na przygnębienie, napawa nadzieją.

Jedziemy dalej, na zachód. Przez Kutno przejeżdżaliśmy chyba ze trzy razy. W Pile miałam groteskową przygodę, która mogła zakończyć się tragicznie. Zapamiętałam 
ją do dziś, dlatego mogę opisać. Razem z nami jechał mój ojciec, który nie mógł wyjechać w listopadzie 1945 r. razem z matką i braćmi, bo musiał likwidować gospodarstwo i regulować należności wobec państwa. Ponieważ na załadowanie naszego transportu dostarczono dostateczną ilość wagonów, nam, jako dla 2 rodzin, przydzielono mniejszy, ale cały wagon. Dzięki temu inwentarz żywy mogliśmy zatrzymać przy sobie. Było tak i wygodniej, i bezpieczniej. Wieźliśmy 2 krowy, i ojca i naszą, dwoje prosiąt ojca, dwoje naszych i trzy kury ojca. Na stacji w Pile coś mnie podkusiło, by wypuścić kury z klatki i pokarmić je na środku wagonu. Kury tylko na to czekały. Przez otwarte drzwi natychmiast wyfrunęły na zewnątrz. Gdyby to były moje kury pożegnałabym się z nimi, ale to były kury ojca, a ojciec ogromnie mocno przeżywał najmniejsze straty. Zaczęliśmy więc te kury łapać. Stacja duża, pociąg stoi przy pociągu. Kury przebiegały pod wagonami z toru na tor, a my za nimi. Ojciec zły pokrzykuje na mnie, ja z desperacką odwagą biegam za kurami. Ludzie mieli ucieszne widowisko i nie żałowali nam pokpiwań. Jeszcze dziś na wspomnienie tego przemykania się pod wagonami pociągów stojących pod parą cierpnie na mnie skóra. Nie chcę myśleć, co by było, gdyby któryś akurat ruszył z miejsca. Doprawdy nie wiem, jak nam się udało, ale połapaliśmy te kury.

Jedziemy dalej. Przygód nie brakuje, chociaż może nie tak są groteskowe, jak tamta w Pile z kurami. Jesteśmy coraz dalej na zachodzie Polski. Im dalej na zachód, tym większe pustki, tym mniej widzimy ludzi. Zespół wagonów transportu coraz krótszy, bo prawie na każdej stacji wagon odczepiają i repatrianci zostają. Nas też zapytują, gdzie chcemy jechać, gdzie mamy zamiar osiedlić się. Ale my w najmniejszym stopniu nie orientujemy się w geografii tych ziem i w ogóle nic o nich nie wiemy. Matka pisała z jakiegoś Drawska, no to możemy jechać do tego Drawska.

Po dwóch tygodniach podróży w towarowym wagonie razem $\mathrm{z}$ krowami, prosiakami i kurami znaleźliśmy się w całkiem wyludnionej okolicy. Kiedy pewnego ranka, a było to 2 maja 1946 r., obudziłam się nieco później, stwierdziłam że stoimy, a wokół panuje cisza. Zaciekawiona wyjrzałam z wagonu. I cóż ujrzałam? Otóż nasz wagon stoi samotnie na bocznicy kolejowej jakiejś małej stacyjki, nigdzie nie widzę żywego ducha, wokół cisza i spokój, na bezchmurnym niebie słońce wzbiło się już wysoko i przypieka dość mocno. Rozglądam się naokoło i spostrzegam napis na stacji: Drawsko Szczecińskie. Aha, więc jesteśmy na miejscu. Tylko gdzie udać się po informacje, kogo zapytać, kiedy nikogo nie ma. Postanawiam wyruszyć do miasteczka, by odszukać matkę. Wyglądam okropnie. Ręka na brudnym temblaku, bo przed wyjazdem potłukłam się na motorze, sukienka zmięta i też nie grzeszy czystością, na nogach sukienne kapce. Ale co mi tam! Wszystko mam przecież spakowane, prać w drodze nie mogłam, bo to i wody brak, i ręka w bandażach. Idę do miasta w tych wojłokach, chociaż słońce przygrzewa jak w lipcu.

Nie mam kogo zapytać o drogę, na ulicach panują pustki, bo to niedziela. Idę zatem prosto przed siebie, potem skręcam w tę ulicę, która mi się lepiej podobała, gdyż jest zadrzewiona. Trafiam do parku i spotykam jakiegoś radzieckiego wojskowego. Pytam go o ulicę Jagiellońską, przy której ma mieszkać moja matka, ale on nie zna takiej ulicy. Słyszę bicie dzwonów i kieruję się w tę stronę, bo przypomniałam sobie, iż matka pisała, że mieszka blisko kościoła. Po krótkim błądzeniu trafiam 
na poszukiwaną ulicę. Ale to nie ulica, raczej zaułek. Mijam pokaźny dom z pruskiego muru, widzę za nim jakiś duży gmach i przycupniętą przy nim jakąś małą chatynkę. I z okna tej chatynki wygląda moja matka! Krzyknęłam radośnie i już witam się z matką i braćmi. Po przywitaniu i ochłonięciu z pierwszego wrażenia rozglądam się po mieszkaniu i stwierdzam, że żyją bardzo skromnie. Dlaczego - pytam - osiedliście w takiej marnej chałupce, przecież widziałam w mieście tyle pięknych domów? Wyjaśniają mi, że te piękne domy zajęli wcześniej ci, którzy tu byli od początku: a więc wywiezieni na przymusowe roboty lub żołnierze. Wiele domów zajmują żołnierze radzieccy albo siedzą w nich jeszcze Niemcy. O dobre mieszkanie jest i było trudno, zwłaszcza samotnej kobiecie z małoletnimi dziećmi. Ten ogromny budynek, który zwrócił moją uwagę, to młyn zamieniony na magazyn. Pilnują go żołnierze radzieccy i matka w ich sąsiedztwie czuje się bezpieczniej, gdyż, jak się okazuje, grasują tu jeszcze bandy, rekrutujące się z niedobitków hitlerowskich. Wkrótce przekonałam się, że te obawy nie były bezpodstawne. W parę tygodni później brałam udział w manifestacyjnym pogrzebie szefa powiatowego urzędu bezpieczeństwa zastrzelonego z zasadzki w lesie szczecineckim. Podobno była to robota band hitlerowskich.

Kiedy wróciłam na stację, zastałam jakiegoś przedstawiciela PUR- $\mathrm{u}^{15}$.Zadowolony, że mamy się gdzie zatrzymać i w ten sposób uwalniamy go od kłopotu zakwaterowania nas, wkrótce przysłał parokonną platformę do przewiezienia naszych rzeczy. Domek zajmowany przez matkę chociaż niepokaźny z zewnątrz, był pakowny od wewnątrz, bo miał po kilka pokoików na parterze i piętrze. Całe piętro dotychczas było wolne i teraz my je zajmujemy. Nadeszli sąsiedzi, by nas poznać i wypytać o nowiny z naszych stron. Przyszli też zaprzyjaźnieni z matką i braćmi bojcy. Mój dwuipółletni synek umiał parę rosyjskich piosenek. Te piosenki w dziecięcym wykonaniu tak wzruszyły żołnierzy, że obdarowywali dzieciaka, czym który mógł. Jeden przyniósł słodyczy, drugi ciepłą bieliznę itp.

Zaczęliśmy z mężem rozglądać się za pracą i lepszym mieszkaniem. Ale i o jedno, i o drugie nie było łatwo. Domy całe czy może odremontowane były zajęte. Domy nie zamieszkałe były porządnie zniszczone podczas działań wojennych lub zdewastowane przez szabrowników czy po prostu przez tych, którzy kosztem budynków więcej zniszczonych czy stojących pusto naprawiali domy zajęte przez siebie.

Pracy w mieście też nie mogliśmy znaleźć. Z opowiadań matki i braci dowiedziałam się, że oni mieli bardzo trudne początki. Okradzeni jeszcze na stacji załadunkowej, stłoczeni wraz z 10 rodzinami w jednym towarowym odkrytym wagonie jechali przez cały listopad przy nieustającym deszczu. Matka wtedy tak się przeziębiła, że już nigdy nie odzyskała straconego zdrowia. Przyjechali bez środków do życia, bo nie mieli ani pieniędzy, ani żywności. Matka chora, bracia niepełnoletni. Z początku nieraz cierpieli głód, utrzymując się tylko z zapomogi PUR-u. Potem starszy brat

15 PUR - Państwowy Urząd Repatriacyjny został powołany na mocy dekretu Polskiego Komitetu Wyzwolenia Narodowego z 7 X 1944 r. Jego zadaniem było organizowanie i koordynowanie przesiedleń ludności polskiej z rodzinnych stron, głównie z Kresów Wschodnich, na teren Polski pojałtańskiej, czyli na Ziemie Zachodnie i Północne. 
dostał pracę przy obsłudze traktorów, dostali kartki żywnościowe, brat otrzymał pierwsze wynagrodzenie i już dawali sobie radę. Ale jak matka wspominała, cierpieli taką biedę, że nie mieli za co wykupić przydziału żywności na kartki. Myśmy byli w lepszej sytuacji, bo mieliśmy krowę i zapasy żywności.

Z pracą było trudno. Życie dopiero tu się organizowało. Nie było jeszcze tego rozmachu, jaki zapanował kilka lat później. Na szczęście mąż znalazł zatrudnienie w odległym o $5 \mathrm{~km}$ majątku Suliszewo. Należał on do państwowych nieruchomości ziemskich. Kiedy ładowaliśmy na furgony nasze rzeczy, chciałam zabrać skromne meble, które już zdążyłam kupić u żołnierzy, ale mąż nie chciał nic zabierać, bo rzekomo w majątku wszystko jest.

Jedziemy do Suliszewa. Wjeżdżamy na podwórko majątkowe. Wita nas wysoki, dobrze zbudowany mężczyzna, jak się okazuje rządca gospodarstwa. Wokół zbiera się grupka ciekawskich. Słyszę szepty, że jesteśmy „bogaci”. Sensację budzą klatki z prosiakami i kurami, które ojciec mi oddał, a chyba trochę zawiści krowa uwiązana z tyłu furgonu. Wnosimy rzeczy do mieszkania, które mieści się dość wysoko na piętrze nad stajnią i magazynem z paliwem. Zajmujemy trzy duże pokoje i kuchnię. Po drugiej stronie korytarza stoją puste liczne pokoje oraz kuchnia. Te meble, o których mówił mąż, to żelazne o powyginanych prętach łóżka i z niemalowanych desek wąskie, wojskowe szafy. Proszę rządcę o konie i jutro sprowadzam meble z miasta.

Mąż pracuje jako magazynier. Ja zabieram się do gospodarstwa domowego. Doprowadzam do porządku mieszkanie, oporządzam inwentarz, w wolnych chwilach poznaję sąsiadów. Okazuje się, że w majątku pracuje sporo Niemców. Nie znam niemieckiego, toteż nie mogę się z nimi porozumieć. Polacy stanowią mniejszość, za to pochodzą ze wszystkich stron Polski i różne drogi ich tu przywiodły. Rządca i my pochodzimy zza Bugu, z północy, druga rodzina Zabugowców wywodzi się z południa: mąż został tu po zdemobilizowaniu, a żona uciekając przed bandami banderowców, przyjechała z dziećmi do męża. Karbowy - z jakiejś wsi spod Kutna poznał swoją żonę warszawiankę na robotach w Niemczech. W drodze powrotnej do kraju tu się zatrzymali. Podobnie traktorzysta. Do drugiego traktorzysty wraca ojciec z Anglii, gdzie dotarł z armią Andersa. Parę rodzin fornalskich przyjechało z Kieleckiego. Później dojdą jeszcze Ukraińcy z akcji „W”. Każda grupka regionalna na razie trzyma się oddzielnie. Przyjaźń czy bliższą znajomość zawiera się na zasadzie pochodzenia z jednej lub sąsiedniej miejscowości. Czyni się nawet dość energiczne poszukiwania współziomków. Każdy „ze swojej strony” witany jest jak brat. Bo razem jakoś raźniej. Najbardziej zagubieni czują się Zabugowcy. Wyrwani ze swego środowiska, od rodziny i sąsiadów, bez nadziei powrotu do swych gospodarstw i domów, które nieraz z takim trudem zdobywali czy budowali, czują się niepewnie w nowym otoczeniu. Oni też są najczęściej obiektem żartów ze strony Centralniaków. „Mały konik i duga, pewnie człowiek zza Buga” - kpią Centralniacy. „Jeden dysel, jeden kuń, człowiek z naszych strun” - odcinają się Zabugowcy. Ale wzajemne dokuczanie sobie nie ograniczało się tylko do takich niewinnych żartów. Bolą epitety „chamów zza Buga”. Niewiele pomagają uwagi, że w takim razie do tych „chamów” należałoby zaliczyć Mickiewicza, Słowackiego, Orzeszkową, bo też pochodzili „zza Buga”. Autorzy tych wyzwisk najczęściej niewiele słyszeli o Mickiewiczu 
i Orzeszkowej. Bo różni tu są ludzie. Z Polski Centralnej jedni są oddelegowani przez macierzyste instytucje i zakłady pracy, by tu organizowali administrację państwową, uruchamiali zakłady przemysłowe itp., inni przyjechali z przeludnionych wsi, by objąć poniemieckie gospodarstwa, ale też zleciało się tu wiele niebieskich ptaków, amatorów łatwych zysków, szabrowników różnego typu. To oni, ci kombinatorzy, tylko czekają, by okpić „chama zza Buga”.

Nie zawsze i tak zwane „czynniki” wiedziały, jaką zająć postawę. Do historii już przeszło wystąpienie pewnego działacza politycznego, który wszedłszy na mównicę, w ten sposób odezwał się do zebranych: „Obywatele i obywatelki! no... i wy ludzie zza Buga”.

Ale Zabugowcy, najczęściej cisi i pracowici ludzie, znali swoją wartość. Chętnie powtarzali anegdotę, według której kiedy Zabugowiec bierze pożyczkę na zagospodarowanie się, to pyta przede wszystkim, kiedy ma spłacić pierwszą ratę, a Centralniak tylko interesuje się, kiedy otrzyma następną pożyczkę. Z czasem animozje zanikały, wzajemne kpinki ustawały. Rodziła się jedna społeczność. Jak zwykle pierwsze lody przełamali młodzi. Zaczęły się kojarzyć mieszane małżeństwa. Powstawały nowe związki rodzinne, według innych kryteriów dobierali się przyjaciele itp. Dzisiaj młode pokolenie nie bardzo nawet wie, skąd wywodzą się rodzice. Nie interesują się tym. Już się wykształcił lokalny patriotyzm. Jeżeli są jakieś antagonizmy, to ich podłożem jest rywalizacja sąsiadujących miasteczek czy wsi tu, na tych ziemiach, rywalizacja wynikła z miejscowych ambicji.

Niedożywiani podczas wojny i okupacji ludzie mieli już dość głodówki, pragnęli w końcu jeść do syta. Tymczasem początki były trudne, bardzo, chociaż wszyscy energicznie zabrali się do hodowli i uprawy. Pensje były mniej niż skromne. Mój mąż zarabiał miesięcznie 200 zł (dwieście), co nie równoważyło nawet wartości 1 kg masła. Dochodziła jeszcze ordynaria, która obejmowała 21 mleka dziennie lub utrzymanie dla krowy. Myśmy mieli krowę, to nam mleka starczało, ale ci, którzy otrzymywali te 21 dziennie i nie mieli okrasy, to mieli krucho.

Wszystkie rodziny pracujące $\mathrm{w}$ majątku otrzymały z UNRRy po rasowym prosiaku. Dobra rasa wymaga dobrych warunków. Ja mleka prosiakowi nie żałowałam, toteż mój rósł jak na drożdżach, ale inne gospodynie niewiele z tych 2 litrów mogły wydzielić swoim prosiakom. Nic dziwnego, że nie rosły. Ale o dziwo zauważyłam, że moi sąsiedzi z jednej strony zazdroszczą mi przybierającego szybko na wadze wieprzka, a z drugiej strony chlubią się nim przed obcymi i podziwiają. Nieraz zastałam stojących przed klatką z wieprzem, wpatrzonych w niego z zachwytem rządcę lub fornali. Wprost ślinka płynęła im do ust na widok żywych szynek. Wszystkich gości z zewnątrz zaraz prowadzili do chlewa i pokazywali z dumą opasłego świniaka. Zrozumiałam, że mój wieprzak był dumą całego majątku. Rzeczywiście rósł bardzo szybko i kiedy miał 10 miesięcy wieku, ważył około $200 \mathrm{~kg}$. Kiedy przyszedł czas, by go zabić, przychodzili wszyscy oglądać grubość słoniny. Przypomniałam sobie, że w naszych stronach istniał zwyczaj obdzielenia sąsiadów mięsem z zabitego wieprza, tzw. świeżaniną. Chociaż Centralniacy szydzili z wielu naszych zwyczajów, byłam pewna, że z tego zwyczaju kpić nie będą. Wzięłam najgrubszy połeć słoniny, podzieliłam na tyle części, ile było rodzin polskich w majątku, dołożyłam trochę mięsa i obdzieliłam wszystkich. Niech jedzą i wspominają. 
Jedna z moich kur wcześnie zakwoktała. Chciałam ją nasadzić, ale miałam za mało jajek. Inne gospodynie w majątku nie miały kogutów, poszłam więc pożyczyć czy kupić jaj do gospodyni rządcy. Ta sama nie chciała decydować i odesłała mnie do rządcy. Kiedy mu wytłumaczyłam swoją prośbę, o mało z wrażenia nie spadł z krzesła. „Już pani nasadza kurę!” - zawołał z największym zdumieniem. Rzeczywiście było jeszcze wcześnie. A w tym dniu, jak to często bywa w marcu, przez cały dzień szalała zamieć śnieżna. Po kilku tygodniach sąsiedzi zauważyli brak na podwórku mojej drugiej kury. Domyśleli się zaraz, że już i drugą nasadziłam na jajach. Teraz moja opinia dobrej gospodyni ugruntowała się na dobre. Dzisiaj, kiedy ze sztucznych wylęgarni otrzymujemy tysiące kurcząt dziennie, a gospodarstwa rolne dostarczają tony tuczników, nasze współzawodnictwo we wczesnym nasadzaniu kwok czy zasiewaniu warzyw wydaje się być może śmieszne. Ale dla nas wtedy nie były to sprawy błahe. Byliśmy wszak pionierami na tych ziemiach. Zaczynaliśmy prawie z niczego.

Wraz ze wzrostem dobrobytu mijał powoli romantyzm pierwszych pionierskich dni. Chociaż dalej miałam osiągnięcia w hodowli i uprawie, świnki i kurki już nie zaspokajały moich ambicji. Zawsze pragnęłam się uczyć, ale na spełnienie moich marzeń nie pozwalały warunki materialne rodziny, toteż zamiast do gimnazjum posłano mnie na naukę szycia. Szyć nie lubiłam, ale teraz szyłam sąsiadkom, żeby w ten sposób wspomóc budżet domowy. Prowadziliśmy dość ożywione życie towarzyskie. Do majątku przybył nowy rządca, przyjechał księgowy z żoną. Odwiedzaliśmy się wzajemnie, wieczorem często jeździliśmy do kina do Drawska, ale to wszystko nie dostarczało mi pełnego zadowolenia z życia. Chciałam coś w życiu osiągnąć, wznieść się wyżej. Odczuwałam niedosyt wiedzy. Co prawda dużo czytałam, byłam kolporterką Klubu Dobrej Książki, pracowałam społecznie jako przewodnicząca Koła Ligi Kobiet, ale czułam, że to wszystko było nie to, czego chciałam. Toteż kiedy dowiedziałam się z „Przyjaciółki”, że są możliwości zdobywania wykształcenia drogą korespondencyjną przez ludzi dorosłych, od razu zgłosiłam się do szkoły. W ten sposób rozpoczęłam naukę w gimnazjum humanistycznym w Warszawie prowadzonym przez Towarzystwo Uniwersytetów Robotniczych i Ludowych. No i zaczęła się harówka.

Uczyć się mogłam jedynie późno wieczorem, kiedy mąż i syn już spali. Wtedy po całodziennej pracy w gospodarstwie lub w ogrodzie czy na polu mogłam zabrać się do książek. Czasem wieczorem wypisywałam na kartce słówka łacińskie lub rosyjskie i jutro idąc do pracy na pole, powtarzałam z karteczki. Albo dla urozmaicenia w takt uderzeń motyki o ziemię odmieniałam: terra, terrae, terris itd.

Mąż niewiele interesował się domem, toteż i moja nauka nic go nie obchodziła, byle wszystko było zrobione w gospodarstwie na czas. Sąsiedzi natomiast nie mogli mnie zrozumieć. Dziwili się nieraz, po co mi nauka, kiedy już mam męża, dziecko, gospodarstwo, a więc w ich przekonaniu życie ustabilizowane. Dotychczas nikt nie słyszał, żeby człowiek dorosły , „matka dzieciom” odrabiała lekcje, rozwiązywała zadania z matematyki. Dopóki zarabiałam, szyjąc - miałam uznanie, ale od kiedy zaczęłam się uczyć - wywoływałam tylko zdziwienie. Dzisiaj oświata dorosłych, zdobywanie wykształcenia systemem zaocznym stały się zjawiskiem powszechnym i zrozumiałym, nie dziwi nikogo, ale wtedy byłam pierwszą jaskółką w tej dziedzinie, był to wypadek bez precedensu i ludzie nie wiedzieli, jak się do tego ustosunkować. 
Jak już wspomniałam, życie w majątku toczyło się bardzo wesoło i przyjemnie. W tym samym budynku, w którym myśmy mieszkali, mieściła się kancelaria majątkowa. Właściwa praca zaczynała się w niej dopiero pod wieczór, po powrocie robotników z pola. Przez większość dnia pracownicy biura obijali się. Nic zatem dziwnego, że biuro stało się miejscem spotkań mieszkańców majątku. Stróż sypał dowcipami, księgowy opowiadał kawały, jego żona kokietowała kasjera. Aż się bałam, że to może źle się skończyć, bo jest nam za wesoło.

Przeczucia mnie nie omyliły. Pewnego późnego wieczora, kiedy cały majątek był już uśpiony, tylko ja siedziałam nad matematyką, posłyszałam w nocnej ciszy jakiś zdławiony krzyk. Kiedy wsłuchałam się uważniej, poznałam głos nocnego stróża. To on zdławionym z przerażenia głosem wołał: „ratujcie ko...nie...! Ra...tujcie konie!” Wyjrzałam przez okno i zobaczyłam ogień w stajni. „Wstawaj!” krzyknęłam do męża - „pali się!” i zbiegłam na dół, by dzwonić na alarm. Na bicie dzwonu zaczęli nadbiegać ludzie. Wtedy pobiegłam do obory i odwiązałam kilka krów. Ludzi nadbiegało coraz więcej, rządca zaczął kierować gaszeniem pożaru i ratowaniem inwentarza żywego. Najwięcej trudności sprawiały konie, które nie chciały wyjść z płonącej stajni. Kilka koni nawet poparzyło się poważnie i weterynarze nie wróżyli im ocalenia, ale na szczęście przepowiednie te okazały się fałszywe i konie wyzdrowiały. Straty były ogromne. Mimo energicznej akcji ludności i straży ogniowej stajnia, obora i chlewnia oraz znajdujące się nad nimi magazyny zbożowe spłonęły doszczętnie. 8 mln zł uleciało z dymem.

Podczas śledztwa okazało się, że to stróż był sprawcą pożaru, do czego zresztą od razu się przyznał. W stajni nie było oświetlenia elektrycznego i stróż przyświecał sobie naftową latarnią. Korzystając z tego, podkradał naftę. I tym razem chciał nadlać nafty z latarni do butelki. Z płonącej latarni. Skończyło się pożarem. Stróża zamknięto, a przy okazji aresztowano rządcę. Za to, że nie było oświetlenia elektrycznego. Jakby to od niego zależało! Założenie instalacji elektrycznej miało kosztować cały milion i wchodziło w plany inwestycyjne.

Po miesiącu rządcę zwolniono, a stróż dostał 6 mies[ięcy] więzienia. Życie w majątku nie powróciło do dawnego stanu. Znikł bezpowrotnie poprzedni nastrój beztroskiej wesołości. Atmosferę zatruwał swąd spalenizny dosłownie i w przenośni. Rządca zrażony i rozgoryczony przeniósł się w Poznańskie. A szkoda, bo to był dobry gospodarz i organizator. Ja zaczęłam zastanawiać się nad uregulowaniem swego życia osobistego. Moje małżeństwo okazało się pomyłką. Mąż, nałogowy alkoholik, nie umiał i nie chciał dostosować się do wymogów życia rodzinnego. Nie tylko nic nie dawał na utrzymanie rodziny, przepijając całe swoje wynagrodzenie, ale jeszcze po powrocie z knajpy urządzał karczemne awantury. Do tego dochodziła nieuzasadniona zazdrość. Z czasem zaczął nastawać na moje życie. Zrozumiałam, że muszę ratować siebie i dziecko. Od dawna przemyśliwałam nad rozejściem się, ale przeżywałam wiele wahań i rozterek. Nie chciałam brać na siebie odpowiedzialności za rozbicie rodziny, za pozbawienie dziecka ojca. Ale kiedy uświadomiłam sobie, że właściwie nie stanowimy rodziny, a dziecko nie ma przecież żadnej opieki ze strony ojca, lepiej będzie jeśli dziecku zapewnię spokój, uwalniając od awantur alkoholika. Wpływały też obawy innej natury. Nie byłam pewna, czy potrafię zarobić na utrzymanie swoje 
i dziecka. Bałam się zaczynać życie od nowa. Obliczałam nieraz, ile to nas może kosztować śniadanie, ile obiad i kolacja, ile muszę na to zarobić i lęk mnie brał, czy potrafię sprostać swoim obowiązkom. Ale coraz częściej zdawałam sobie sprawę, że dłużej męczyć się nie mogę. Szalę wahań przechylił fakt przepicia przez męża w ciągu dwóch dni 24 tys. zł uzyskanych za sprzedaną świnię, którą rok chowałam. Do rozejścia się namawiała też mnie matka, nie mogąc patrzeć na moją krzywdę. Zdecydowałam się.

Dzięki pomocy powiatowej instruktorki Ligi Kobiet dostałam pracę w Powiatowym Zarządzie Drogowym. Trudniej było o mieszkanie. W tym czasie przystąpiono u nas do kolektywizacji wsi i były trudności nie tylko ze znalezieniem mieszkania w mieście, ale nawet i z zameldowaniem się. Zatrzymywano ludzi do pracy na wsi. Kiedy $\mathrm{w}$ biurze kwaterunkowym prosiłam o przydzielenie mi pokoiku na piętrze w domu zajmowanym przez matkę (już przy innej ulicy i w lepszym budynku), bo tam dziecko znajdzie opiekę, gdyż ja po rozejściu się z mężem muszę iść do pracy, usłyszałam, że pokoiku nie otrzymam i mam żyć z mężem. Nie wiedziałam jeszcze wtedy, że głupstwa może mówić także i petent, nie tylko urzędnik, więc tylko pokornie spuściłam głowę i ze łzami w oczach wyszłam. Potem dawano mi jakiś pokój na poddaszu w innej części miasta, w końcu po wielu zabiegach i prośbach otrzymałam przydział na pokoik, o który się ubiegałam. Był to wykorzystywany dotychczas na komórkę pokoik bez kuchni, pieca, gazu, wody i światła, bez szyb, z dziurami w ścianach, ale za to przy matce. Własnym kosztem doprowadziłam go do jakiego takiego stanu i zamieszkałam. Było to w marcu 1950 r. Na razie o piec nie martwiłam się.

Zaczęłam pracować w Zarządzie Drogowym. Nie umiałam nic, ale szybko uczyłam się, a w pracy nie leniłam się. Hej, co to były za czasy. Okres pięciolatek, ogromnych inwestycji, rozmachu... i ogromnych błędów. Ludzie byli na wagę złota. Każdego przyjmowano do pracy, gdzie chciał. Ja, pamiętająca okresy bezrobocia, które przeżywał mój ojciec przed wojną, wysoko zawsze ceniłam i cenię pracę, możliwość stałego zarobku, będącego podstawą utrzymania. Toteż garnęłam się do pracy, jak mogłam. Ten mój stosunek do pracy został w swoisty sposób wykorzystany przez przełożonych. Byłam referentem dróg powiatowych i pracowałam w księgowości. Księgowy stale zatrudniał mnie po godzinach pracy w biurze. Jak się później przekonałam: całkiem bezprawnie i niepotrzebnie. On uciekał do biura od niekochanej żony i od pracy domowej. Dlatego czas przedpołudniowy spędzał w biurze na pogaduszkach, a do księgowania zabierał się wieczorem. Żeby mu się nie nudziło, kazał przychodzić do pracy wieczorem i nam, młodszym pracownikom. Moja koleżanka miała większą praktykę biurową i nic sobie nie robiła z jego poleceń. Zostawała rzadko, ale ja wierzyłam w nawał pracy i posłusznie przesiadywałam do 11 wieczorem.

W tym czasie wykonawcy robót mogli sami przygotowywać dokumentację techniczną. Kierownik naszego biura, inżynier opracowywał sam projekty i kosztorysy budowanych później przez Zarząd Drogowy mostów i dróg. Były to prace zlecone, za które brał dodatkowe wynagrodzenie. Myśmy nieraz mu w tym pomagali, oczywiście w ramach naszych zajęć, bo nie wiedzieliśmy, że to były prace dodatkowe, dodatkowo opłacane. Najczęściej naturalnie ja byłam do tych prac zatrudniana. Nic zatem dziwnego, że kiedy z uzyskanych oszczędności przyznano nam premie, poczułam się pokrzywdzona, otrzymując tyle samo co i inni, którzy nie pracowali dodatkowo. 
Pierwszym mostem, który nasza instytucja wybudowała, był most na Dranie na ul. Gen. Świerczewskiego. Nie bardzo mi się podobał, bo jest ciężki, zwalisty, ale że pierwszy w mojej karierze drogowca, to pozostał na zawsze jakiś bliski, swój. Potem budowaliśmy inne, ale ten najmocniej utkwił w pamięci. Ile razy nim przechodzę, tyle razy uświadamiam sobie, że tu jest i cząstka mojej pracy, mego wysiłku. Zapamiętałam też pierwsze odcinki dróg wtedy budowanych a były to: OlesznoBucierz-Konotop i Mirosławice-Sosnica-Czaplinek.

Pewnego razu spotkany na ulicy inspektor oświaty zaproponował mi pracę w inspektoracie. Zgodziłam się, bo przypomniałam sobie, że to będzie doskonała zemsta na moich zwierzchnikach za krzywdzącą premię.

Wtedy o ludzi do pracy było trudno i odejście cenionego pracownika było dotkliwą stratą. Ponadto zawsze chciało mi się pracować w placówce kulturalnej czy oświatowej. Naukę już przerwałam, bo po powrocie późno z pracy nie byłam w stanie ślęczeć nad książkami. W pewnym stopniu przyczyniła się do tego reorganizacja szkoły. Nie znajdowałam też ani zrozumienia, ani poparcia w zakładzie pracy. Kierownik mówił często, że nie wyobraża sobie nauki bez osobistego kontaktu ucznia z nauczycielem. Wykształcenia od nikogo nie wymagano. Wystarczyły dobre chęci i trochę zdolności, a czasem pewność siebie, tupet. Byli przecież dyrektorzy bez ukończonej szkoły podstawowej. Ja miałam 2 semestry gimnazjum i to było już dużo.

Kierownik Zarz[ądu] Drogowego za nic nie chciał mnie zwolnić, ale uparłam się, przekabaciłam na swoją stronę radę zakładową i odeszłam. Kiedy jednak zgłosiłam się do pracy w nowym miejscu, dowiedziałam się, że przeznaczone dla mnie stanowisko jest zajęte i muszę zadowolić się niższą grupą. Mogłam wrócić na stare miejsce, przyjęliby mnie z otwartymi rękami, ale ambicja nie pozwoliła mi już na to, więc zostałam w inspektoracie. Tu nie musiałam zostawać po godzinach pracy. Kierując samodzielnie referatem, mogłam zorganizować pracę tak, by wykorzystać w pełni czas urzędowania, pracować racjonalnie i sprawnie. Dzięki temu mogłam zmieścić się w przepisowych godzinach pracy, chociaż roboty nie brakowało.

Zaraz po objęciu przeze mnie referatu opieki nad dzieckiem zjawili się drawscy kolejarze z pretensją, że oni od dawna ubiegają się o otwarcie świetlicy dworcowej dla młodzieży szkolnej, mają na ten cel przeznaczone pomieszczenie i sprzęt, a inspektorat oświaty świetlicy nie otwiera. Postanowiłam wykorzystać okazję i zaraz zakrzątnęłam się koło tej sprawy. Ale tu natrafiłam na trudności. Nie było żadnego regulaminu ani zarządzenia określającego ilość godzin pracy, charakter tej pracy, wysokość wynagrodzenia za opiekę itd. Nie znalazłam żadnych wytycznych w Kuratorium. Musiałam opierać się na intuicji, kierować się wyczuciem. Niełatwo przyszło znaleźć opiekuna świetlicy i sprzątaczkę. W końcu doszło do otwarcia świetlicy. Była to pierwsza uruchomiona przeze mnie placówka. Czynna jest do dziś. Zachęcona powodzeniem postanowiłam otworzyć drugą świetlicę dla młodzieży na stacji w Złocieńcu. Ale tu kierownictwo stacji nie życzyło sobie świetlicy, bo w wolnym pomieszczeniu zamierzano uruchomić restaurację. Długo trwała walka o lokal. 
Poruszyłam wszystkie sprężyny, atakowałam DOKP ${ }^{16}$ w Szczecinie, w końcu sprawę wygrałam. I w Złocieńcu do dziś istnieje świetlica dla młodzieży szkolnej.

Kiedy już obie świetlice funkcjonowały, przyjechała wizytatorka z Koszalina, by zapoznać się z regulaminem naszych świetlic. Na podstawie danych zebranych $\mathrm{w}$ naszym powiecie $\mathrm{i} \mathrm{w}$ innych powiatach województwa opracowano zarządzenie i wytyczne do pracy świetlic dworcowych. Podobnie rzecz się miała z instrukcjami dotyczącymi pracy innych działów referatu opieki nad dzieckiem. Kiedy po objęciu kierownictwa referatu pojechałam do Kuratorium, by tam uzyskać jakieś wskazówki do pracy i zapoznać się z obowiązującymi przepisami, wysłano mnie po instrukcje do kierowniczki ref[eratu] op[ieki] nad dzieckiem w powiecie Koszalin, bo w Kuratorium sami nie mieli zarządzeń i nie bardzo orientowali się w pracy powiatów.

Trzeba było sobie samym radzić, toteż i radziliśmy. Otwierałam dziecińce, organizowałam świetlice szkolne $\mathrm{z}$ dożywianiem i bez, kolonie i półkolonie, wczasy w mieście, wycieczki dzieci wsi do miast, wczasy dziecięce w zimie itp. Przygotowaniem teoretycznym były konferencje i kursokonferencje, a także kursy dłuższe, nawet miesięczne. Dzieliliśmy się między sobą doświadczeniami, zdobywaliśmy praktykę i pracowaliśmy ponad siłę. Referat opieki nad dzieckiem był najcięższym i najpracowitszym działem inspektoratów. Kiedy z ref[eratu] op[ieki] n[ad] dz[ieckiem] wyłączono w osobny referat wychowanie pozaszkolne, odpadły przynajmniej konkursy, eliminacje, wystawy, popisy itp. Musiałam za to objąć oświatą dorosłych, ale to już była fraszka w porównaniu do innych obowiązków.

Dzisiaj wszystkie te sprawy zostały unormowane, uporządkowane przepisami, dopracowano się wielu usprawnień, dzięki czemu pracownicy inspektoratów odpowiedzialni za wczasy letnie dla dzieci i młodzieży oraz opiekę nad dzieckiem mogą latem korzystać z urlopów. Wtedy nie do pomyślenia było, żeby ktoś z nas mógł pozwolić sobie latem na urlop. Dopiero po zakończeniu całkowitym akcji letniej, a więc gdzieś w końcu listopada można było liczyć na odpoczynek. Od maja do października żyliśmy jak w gorączce. Najgorzej dawały się we znaki remonty i zaopatrzenie w sprzęt. Przy ówczesnych brakach w zaopatrzeniu i braku materiałów budowlanych te sprawy spędzały nam sen z powiek. Wtedy kupienie łyżki było problemem, a zdobycie większego garnka sukcesem na miarę dzisiejszych lotów kosmicznych! (No cóż, przesadzić trochę mam chyba prawo!) Ale jak było naprawdę, niech opowie następujący fakt. Otóż zamówiliśmy w Koszalinie w „Argedzie” większą ilość 50-litrowych garnków, o których zdobyciu w naszym miasteczku nawet nie mogliśmy marzyć. Ale „Arged” nie realizował i nie realizował naszego zamówienia. Po pół roku chyba, a może i później pojechał jeden z naszych pracowników po te garnki. Kiedy i tym razem chciano zbyć go niczym - zrobił awanturę nie z tej ziemi. Ponieważ nie grzeszył kulturą, sądzę, że tamtejszym pracownikom dobrze się dostało, bo zaraz wpłynęła od nich skarga na naszego przedstawiciela. Ale garnki dostał. Kiedy przejeżdżał przez wsie, kobiety biegły za samochodem ze szmatami, sądząc, że przywieziono garnki do wsi na wymianę. 
Trzeba było walczyć o gwoździe, słomę do sienników, na własnych plecach nosić prycze drewniane na samochód lub do magazynu itd. Tylko nasz zapał i samozaparcie mogło w tym prymitywie stworzyć jakieś możliwe warunki dla młodzieży.

Cztery lata mieszkałam $\mathrm{w}$ nieopalanym pokoju, ale nareszcie polepszyły się moje warunki mieszkaniowe. Zmarła sąsiadka, a jej dzieci zamierzały przenieść się do Poznania. Zaproponowałam im zamianę mieszkania. Zgodziły się, a wydział kwaterunkowy zatwierdził zamianę. Teraz miałam dwupokojowe mieszkanie z piecem. I chociaż nadal musiałam gotować na kuchence elektrycznej, bo kuchni nie było, byłam zadowolona z warunków lokalowych. Przed domem był mały ogródek. Odgruzowałam [go], skopałam i zasadziłam kwiaty.

Dwa moje marzenia: mieszkanie i kwiaty już się spełniły. Przyszedł czas i na realizację trzeciego: nauki. Słyszałam, że w Szczecinku istnieje liceum korespondencyjne dla pracujących, które nawet prowadzi filie, m.in. i w naszym miasteczku. I chociaż dalej sprawa wykształcenia była dla mnie sprawą ogromnie drażliwą, dalej odczuwałam tęsknotę za szkolną ławką, a na widok szkolnego mundurka doznawałam bolesnego skurczu serca, sądziłam, że chyba na naukę jest już dla mnie za późno. Z filii w Drawsku korzystali sami młodzi i bardzo niepoważni ludzie. Jakoś nie mogłam wyobrazić siebie wśród nich. Ale pewnego razu do inspektoratu zgłosił się któryś z sekretarzy KP PZPR o adres szkoły średniej dla dorosłych. To mnie zbulwersowało. Więc jak to - myślałam - to on, człowiek na poważnym stanowisku, nie wstydzi się zaczynać nauki, a ja się wstydzę? Jeszcze tego samego dnia napisałam do Szczecinka i wznowiłam naukę. Z początku szło mi ciężko, ale kiedy nadchodziły pokusy, by rzucić naukę, przypominałam sobie, że są przecież tacy, którzy wytrwali i osiągnęli cel. Czyż jestem gorsza? Nie zrezygnuję! I nie zrezygnowałam. Z czasem wciągnęłam się do nauki, zaczęłam otrzymywać coraz lepsze stopnie, a na koniec roku miałam na świadectwie same b[ardzo] dobre oceny. Było ogromnie ciężko godzić pracę, obowiązki domowe i naukę - to fakt, ale wytrzymałam. Nie tu miejsce o tym się rozpisywać, wystarczy, jeżeli wspomnę, że nieraz prosto z pracy bez obiadu trzeba było biec na stację, by zdążyć na pociąg i jechać na konsultacje czy lekcje, które trwały do godz. 21-szej i bez kolacji nocować na sienniku rozłożonym wprost na podłodze, wstać o 3 rano i biec $2 \mathrm{~km}$ na pociąg, potem po nieprzespanej nocy i skromnym śniadaniu, bo nie było czasu na przygotowanie lepszego, śpieszyć do pracy, czasem prosto w teren. Tylko niezwykle serdeczny i opiekuńczy stosunek dyrektora szkoły, nieodżałowanej pamięci mgr. Bucholca, oraz uznanie dla naszego wysiłku ze strony większości nauczycieli podtrzymywało nas na duchu i łagodziło ten ogromny trud.

Po trzech latach dobrnęłam do matury. Zdałam ją bez większych kłopotów z bardzo dobrym wynikiem, mimo to pozostała dla mnie do dziś chyba największym przeżyciem.

W mojej pracy potrzebne mi były kwalifikacje pedagogiczne. Można było je zdobyć w tzw. regionowych komisjach dla czynnych niekwalifikowanych nauczycieli, ale były już one w stadium likwidacji. Jako ostatnia, działała w Szczecinie. Zgłosiłam się i po pokonaniu pewnych oporów zostałam przyjęta. Komisja otrzymała kredyty na 1 oddział, tymczasem nas, niedobitków z całej Polski zebrało się ponad 80 osób. 
Nic zatem dziwnego, że nauczyciele wcale się nie martwili, jeżeli ktoś z nas nie wytrzymał reżimu nauki i odpadł. Wymagano od nas ogromnie wiele, nie zawsze dając nam w zamian tyle samo. Jedni nauczyciele dawali z siebie bardzo dużo, inni dawali przykład, jak pracować nie należy. Na szczęście Kuratorium w Koszalinie zorganizowało w styczniu 1958 r. egzamin eksternistyczny dla nauczycieli niekwalifikowanych. Przyjęto mnie na ten egzamin i zdałam go bardzo dobrze. Ale muszę przyznać, że ogromnie przydały mi się wiadomości zdobyte w Szczecinie.

W czerwcu tegoż roku złożyłam egzamin i zostałam przyjęta na Wydział Zaoczny Filologii Polskiej Uniwersytetu Warszawskiego. Ale kiedy wybierałam się na pierwszą sesję letnią, wyłoniła się nieprzewidziana, zdawało się w pierwszej chwili nie pokonana przeszkoda. Otóż inspektor oświaty, który dotychczas co prawda absolutnie nie interesował się moją nauką, nic nie ułatwiał, ale też i nie utrudniał, nagle stanął okoniem i nie chciał udzielić zezwolenia na wyjazd na sesję. Pod wpływem pożaru fabryki włókienniczej w Złocieńcu wpadł w panikę i obawiał się, że beze mnie zawali się akcja letnia. „Uparłem się i nie puszczę” - mówił. Prosiłam, błagałam, płakałam - na próżno. Zapewniałam, że przesiedziałam w biurze kilka wieczorów, by „zapiąć wszystko na ostatni guzik”, że wszystko przygotowane. W końcu, po kilku dniach i po wielu upokorzeniach, których mi nie szczędził, na podstawie pisemnej zgody kolegi, który obiecał mnie zastąpić, w końcu się zgodził. Jakże szczęśliwa jechałam do Warszawy. Jestem studentką - powtarzałam co chwila.

Aby na przyszłość uniknąć podobnych przepraw, złożyłam podanie o przeniesienie mnie do pracy w szkole. Mając wakacje, pojadę na sesję bez łaski inspektora. Wtedy nie wymagano zgody zakładu pracy na zaoczną naukę pracownika. Ponadto chciałam zdobyć doświadczenie pedagogiczne praktycznie, bo dotychczas miałam przygotowanie do pracy w szkole tylko teoretyczne. Inspektor nie chciał mnie puścić z inspektoratu, ale że w skład komisji rozpatrującej podanie nauczycieli jako prezes związku wchodził kierownik szkoły podstawowej dla pracujących, do której chciałam przejść, moje podanie zostało załatwione pomyślnie.

Od września 1958 r. zaczęłam uczyć w szkole. Znajdowało się w niej wielu uczniów z marginesu społecznego, których usunięto ze szkół dziennych za te lub inne przestępstwa, młodzież zdemoralizowana, której ani się śniło ślęczeć nad książką.

Uczniowie ci sprawiali wiele kłopotów wychowawczych, ale jakoś dawaliśmy sobie radę. Zwiększyłam wymagania, starałam się podnieść poziom nauki, by tym samym podnieść rangę szkoły, która dotychczas nie cieszyła się zbyt dobrą opinią ani wśród nauczycieli, ani w środowisku. Wiele wysiłku poświęciłam pracy wychowawczej. Pewne doświadczenie w pracy z taką młodzieżą już miałam, bo w opiece nad dzieckiem często miałam do czynienia z podobnym elementem.

Z dumą mogę powiedzieć, że moje starania osiągnęły cel. Nasza „wieczorówka” coraz bardziej nabierała cech normalnej szkoły. Niektórzy nasi uczniowie poszli do techników, bo pozdawali egzaminy wstępne z wynikiem dobrym. Do dziś większość uczniów przy każdej okazji objawia swoje zaufanie i szacunek dla nauczycieli. Wybrałam tę szkołę dlatego, bo były tam 2 dni w tygodniu wolne od zajęć szkolnych, które mogłam poświęcić na studia. Z czasem przywiązałam się do uczniów i kiedy pod koniec studiów inspektor oświaty zaproponował mi przeniesienie do 11-latki, 
żal mi było odchodzić, a i uczniowie nie chcieli innego nauczyciela i zabiegali w inspektoracie o to, bym dalej ich uczyła. Ale w 11-latce przygotowywał się do matury mój syn, mogłam tam zarabiać w godzinach nadliczbowych, a w wieczorówce nie było na to warunków. Poszłam więc do 11-latki, a na wieczorówce jeszcze przez parę lat uczyłam dodatkowo.

Studia ukończyłam na pół roku przed terminem z wynikiem bardzo dobrym. Teraz mogłam znów pracować społecznie, a przede wszystkim rozwijać działalność kulturalno-oświatową wśród młodzieży. Miałam nareszcie z kim pracować. Młodzież była chętna, toteż z wielką gorliwością zaczęłam ją przygotowywać do udziału we wszelkiego rodzaju imprezach, jak: apele, wieczornice, akademie, konkursy, wycieczki, zgaduj-zgadula, turnieje itp. Moi podopieczni wkrótce zaczęli się wyróżniać w różnych sprawdzianach wiedzy i umiejętności, zajmując w eliminacjach powiatowych i wojewódzkich czołowe miejsca. Oni otrzymywali nieraz bardzo cenne nagrody, a ja miałam tę satysfakcję, że przygotowuję młodzież do życia i wychowuję na dobrych obywateli.

Pracując z młodzieżą zauważyłam, że młode pokolenie odczuwa bardzo słabe związki z dawnym miejscem pochodzenia ich rodziców i jeżeli podtrzymując stosunki rodzinne, odwiedza miejsca, skąd pochodzą rodzice, to nie przejawia większego zainteresowania tymi stronami ani nie czuje do nich jakiegoś sentymentu. Fakt ten stwierdziłam już w trakcie badań ankietowych przeprowadzonych podczas zbierania materiału do pracy dyplomowej, którą pisałam na temat gwary szkolnej uczniów naszego powiatu. Bliższa znajomość młodzieży wykazała, że jeżeli istnieją jakieś konflikty regionalne, to dotyczą one obecnego, aktualnego miejsca zamieszkania, a podłożem ich jest rywalizacja sąsiadujących ze sobą wsi lub miasteczek we współzawodnictwie w rozwoju gospodarczym i kulturalnym.

Młodzi dumni są z nowych obiektów przemysłowych, z nowych chodników czy osiągnięć regionalnych zespołów muzycznych, śpiewaczych itp. Nie dopytują się, kto jest zza Buga, a kto z Kieleckiego czy Łodzi. W wymowie młodych dzięki nauce, prasie, radiu i telewizji już się prawie nie dostrzega regionalnych różnic językowych. Mówią swoją młodzieżową gwarą, jednakową dla nastolatków całej Polski lub starają się wypowiadać poprawnie, tak jak tego żądają od nich w szkole. A my, starsi pragniemy tylko jednego: pokoju, stabilizacji. Już nie jesteśmy zdolni do tej „wędrówki ludów", jaka miała miejsce dwadzieścia kilka lat temu. Cieszy serce widok nowych osiedli mieszkaniowych, rozbudowa zakładów przemysłowych, w których pracują lub będą pracowały nasze dzieci. Każdy już się zagospodarował, urządził, wrósł w tę ziemię z korzeniami. Za przykład mogą posłużyć moje „dzieje”. Przed kilku laty zasadziłam pierwsze drzewko owocowe. Niektórzy sąsiedzi pokpiwali ze mnie: „Sadzi pani dla Niemców” - mówili. Kiedy mnie zgniewali, odpaliłam: „Niech Niemcy wiedzą, że tu dobrzy gospodarze mieszkaja!!”. To poskutkowało. Moje drzewka już owocują. Posadziłam więcej. Teraz i sąsiedzi zasadzili i żałują, że tak późno. W naszej spółdzielni ogrodniczej młode drzewka są w niej rozchwytywane. Niemało musiałam się starać, żeby zdobyć młode czereśnie.

Zmieniły się moje warunki mieszkaniowe. Przed kilku laty dom, w którym mieszkam poddany był kapitalnemu remontowi. Doprowadzono gaz i wodę. W październiku 
1968 r. kupiłam część domu na własność. Teraz jestem właścicielką trzech pokoi i kuchni. Wybudowałam łazienkę. W tym roku ogrodzę siatką drucianą ogród, wyremontuję budynek gospodarczy.

Syn kończy studia na Wydziale Prawa Uniwersytetu im. Mikołaja Kopernika w Toruniu, ja pracuję nadal, mąż już dawno nie żyje. Teraz pracuję w Pedagogicznej Bibliotece Powiatowej w Drawsku, bo praca w szkole ze względu na zdrowie okazała się zbyt ciężka. Ale nadal utrzymuję ścisły kontakt z moimi byłymi wychowankami. Rośnie stos korespondencji, jaka stale napływa od nich. Przychodzą do biblioteki uczniowie, których nie uczyłam i teraz nie uczę, ale którzy znajdują w bibliotece porady i wskazówki do swej pracy.

Organizatorzy konkursu życzyli, by w pamiętniku uwzględnić przede wszystkim lata po roku 1956. Cóż, kiedy te pierwsze lata, pionierskie mocniej wryły się w pamięć i częściej wracają we wspomnieniach. Dzisiaj życie jest łatwiejsze i tym samym mniej barwne, mniej romantyczne, takie bardziej znormalizowane, szare, codzienne, takie jak wszędzie.

Zastanawiam się, który tydzień z trwania konkursu opisać? No, cóż... 2 dni w tygodniu pracuję przed południem, a 4 - po południu. Jeżeli to jest wiosna lub lato, to po powrocie z pracy i spożyciu posiłku idę do ogrodu. Kopię, pielę, podlewam. Pod wieczór wracam do domu, by obejrzeć dziennik telewizyjny i jakiś program rozrywkowy, jeżeli teatr - to obowiązkowo. W tych dniach, kiedy pracuję w bibliotece od 12-tej, do ogrodu idę z rana. Wieczorem czasem odwiedzam znajomych, czasem idę do kina lub oglądam program telewizyjny, przeglądam prasę albo czytam książki. Jeden dzień w tygodniu przeznaczony jest na tzw. pracę wewnętrzną. Wtedy książek się nie wypożycza, bo albo opracowuję i porządkuję katalogi, albo wyjeżdżam na konferencje rejonowe nauczycieli, by zapoznać czytelników z nowościami wydawniczymi.

Niedzielę poświęcam na spotkania towarzyskie, lekturę, marzenia i wspomnienia. Czasem idę na cmentarz, by odwiedzić grób matki, który znajduje się tuż obok pomnika wzniesionego ku czci poległych żołnierzy polskich. Za pomnikiem w równych szeregach mogiły. Spoczywa w nich ponad 3000 żołnierzy, którzy zginęli w walkach o wyzwolenie Drawska i powiatu.

Lubię swoje mieszkanie. Lubię patrzeć na reprodukcję obrazu Netlera z wierzbami nad wodą o zachodzie słońca. Ten obraz nastraja pogodnie i pobudza do wspomnień. A w ogóle sam obraz to cała historia. Gdyby tak umiał opowiedzieć swoje dzieje. Kupiłam go u żołnierzy radzieckich, którzy weszli w jego posiadanie, zajmując sąsiedni dom. Chciałam zmienić ramę, bo była zniszczona. Kiedy wyjęłam obraz z ramy, okazało się, że jest podklejony polską gazetą: „Robotnikiem”. Ponieważ „Robotnik” był organem PPS, na pewno nie był kolportowany w Niemczech. Stąd wniosek, że obraz został zagrabiony w Polsce.

Często wracam wspomnieniami do Suliszewa. Pamiętam sąsiadów, nawet Niemców. Bo po pewnym czasie do majątku sprowadzono więcej rodzin niemieckich. Jedna $\mathrm{z}$ nich zajęła wolne mieszkanie po drugiej stronie korytarza. Była to matka z dwiema córkami. Ojciec zginął na wojnie. Córki chodziły do pracy w majątku, matka gospodarzyła w domu. Jakoś tak nie wiadomo kiedy, bez najmniejszej inicjatywy z mojej strony zaczęła mnie pomagać. To podłogi pozmywała, to pomogła w praniu. 
Starałam się wynagrodzić ją, czym mogłam: czasem dałam słoniny, czasem masła. Niemka była zadowolona. Miała poczciwą twarz bauerki. Wszystkie nieszczęścia zwalała na wojnę. Ale córki jej nie miały tak dobrodusznego wyglądu. Kiedyś przypadkiem odkryłam $\mathrm{w}$ futerale na okulary zdjęcie młodych Niemek $\mathrm{w}$ mundurach Hitlerjugend. Teraz stały się dla mnie zrozumiałe ich dzikie spojrzenia. Ale Niemki wkrótce wyjechały do Niemiec.

Budzi wspomnienia „mój” most. Założenie projektu i kosztorys nasz kierownik opracował już po wybudowaniu mostu, bo te dokumenty niezbędne były do zatwierdzenia kredytu, inaczej nie dostalibyśmy premii. Takie to były czasy. Teraz jest inaczej. Wszystko unormowano, uporządkowano przepisy. Nie ma miejsca na improwizację. Cieszę się, że rozwija się moje miasto, że z każdym dniem staje się piękniejsze. Z okna mogę obserwować, jak rosną mury wznoszonej przez PSS ${ }^{17}$ piekarni lub jak zjeżdżają samochody do warsztatów naprawczych zarządu drogowego, które niedawno zbudowano. W zarządzie drogowym pracuje mój lokator, młody chłopak po technikum drogowym, bo mam jeszcze na strychu mały pokoik, który odnajmuję. Pieniądze uzyskane za komorne przeznaczam na remont domu. Marzy mi się założenie centralnego ogrzewania, a na to trzeba więcej pieniędzy.

Kiedy chodzę po mieście i oglądam sklepy pełne towarów, to aż mi się wierzyć nie chce, że tak wszystkiego jest w bród. Przed kilkunastu laty rower dostałam na talon, w drodze wyjątku, jako pracownik terenowy. Na radio polowałam ponad rok, a pralkę dostałam przez protekcję. A teraz handel naprasza się z towarami. Klient zaś grymasi. I to dobrze. Niech tak będzie zawsze. Niech budują nowe bloki, w których znajdą mieszkania nasze dzieci. Niech rosną drzewa owocowe, niech owocują dla naszych wnuków. Czekam, by syn ukończył studia, zaczął pracować, ożenił się, a mnie przypadła rola babci rozpieszczającej wnuczków.

No, cóż... Mój pamiętnik dobiega końca. Nie zawiera opisów nadzwyczajnych wydarzeń, bo moje życie nie było takie barwne jak innych. Nie zdobywałam tych ziem $\mathrm{z}$ bronią $\mathrm{w}$ ręku, nie walczyłam $\mathrm{z}$ bandami, nie organizowałam tu administracji państwowej itp. Przyjechałam jak wielu innych i włączyłam się do życia, jakie już tu istniało. Do tego zwykłego, mozolnego życia z walką o chleb powszedni, o zwykłą ludzką egzystencję. Moje dzieje są typowe, ale może dlatego również warto utrwalić je w pamięci, zostawić zapis. Może kiedyś przyda się jakimś socjologom w ich poszukiwaniach i badaniach nad tym okresem w dziejach naszego narodu. 


\section{Bibliografia}

Bezdomna Europa. Migracje po II wojnie światowej we współczesnych badaniach humanistów. Zbiór studiów, red. B. Kromolicka, H. Walczak, Szczecin 2015

Blacharska W., Co to znaczy być „repatriantem”?, [w:] Co kryły walizki „repatriantów”? Informator wystawy. Muzeum Etnograficzne w Poznaniu, kwiecień-wrzesień 2000, Poznań [2000], s. 11-15

Herrmann M., Kresowe korzenie Polaków, Centrum Badania Opinii Społecznej. Komunikat z badań, kwiecień 2012 r. (BS/50/2012), http://www.cbos.pl/SPISKOM.POL/2012/K_050_12.PDF

Jancz-Kostuch B., Wprowadzenie, [w:] Co kryły walizki „repatriantów”? Informator wystawy. Muzeum Etnograficzne w Poznaniu, kwiecień-wrzesień 2000, Poznań [2000], s. 6-7

Jankowiak S., Przemiany narodowościowe na „Ziemiach Odzyskanych” po II wojnie światowej, [w:] „Ziemie Odzyskane” po drugiej wojnie światowej, red. C. Osękowski, G. Strauchold, Zielona Góra 2015, s. $33-44$

Kowalski K., Plan Marshalla. Uwarunkowania i skutki gospodarczo-polityczne, Łódź 2014

Krupecka M., Żeńskie wspólnoty zakonne na Środkowym Nadodrzu w latach 1945-1956, [w:] Władze wobec Kościołów i zwiqzków wyznaniowych na Środkowym Nadodrzu w latach 1945-1956, red. E. Wojcieszyk (Studia i Materiały Poznańskiego IPN, t. 20), Poznań 2012, s. 179-211

Kwilecki A., Z pogranicza socjologii i historii. Elementy warsztatu badawczego, Poznań 2016

Lech H., Zatrzymane w pamięci, [w:] Losy Polaków wysiedlonych z Kresów Wschodnich II RP. Przyjazd na Ziemie Zachodnie (1944-1945) w zapiskach wspomnieniowych 40 lat później, red. B.K. Kubis, Opole 2011, s. 89-164

Niemcy jako problem międzynarodowy po II wojnie światowej, red. S. Sierpowski, Poznań 2010

Osękowski C., Specyfika „Ziem Odzyskanych” po II wojnie światowej. Analiza problemu, [w:] „Ziemie Odzyskane" po drugiej wojnie światowej, red. C. Osękowski, G. Strauchold, Zielona Góra 2015, s. 7-19

Pamiętniki osadników ziem odzyskanych, oprac. Z. Dulczewski, A. Kwilecki, Poznań 1963

Podpatrywanie miasta. Miasto w socjologii poznańskiej 1920-2000, red. S. Lisiecki, J. Kubera, Poznań 2016

Skobelski R., Specyfika polityki gospodarczej państwa na „Ziemiach Odzyskanych” w latach 1945-1970, [w:] „Ziemie odzyskane” po drugiej wojnie światowej, red. C. Osękowski, G. Strauchold, Zielona Góra 2015, s. 45-58

Strauchold G., Jak „Szwaby” (tzw. autochtoni) i „Ukraincy” (tzw. repatrianci) układali niespodziewane wspólne życie na byłych niemieckich ziemiach wschodnich od 1945 roku, [w:] Bezdomna Europa. Migracje po II wojnie światowej we współczesnych badaniach humanistów. Zbiór studiów, red. B. Kromolicka, H. Walczak, Szczecin 2015, s. 69-80

Szczepański J., „Mieliśmy tu raj” - menonici z Wymyśla Niemieckiego, [w:] Polska otwarta czy zamknięta?, red. H. Samsonowicz, Łomża 2016, s. 93-111 
Jakub Isański

\section{Pamiętnik Heleny Wróblewskiej, mieszkanki Ziem Zachodnich}

Streszczenie: Pamiętnik nauczycielki Heleny Wróblewskiej, która przyjechała na Pomorze Zachodnie z Kresów Wschodnich II RP. W powojennej Polsce zdobyła wykształcenie, wykonując najpierw prace biurowe, a następnie spełniając swoje marzenie - po uzupełnieniu wykształcenia, rozpoczęła prace $\mathrm{w}$ zawodzie nauczycielki. Jej losy to ilustracja awansu społecznego, stopniowej i konsekwentnej pracy kobiety, która spisała swoje wspomnienia z perspektywy osoby o stabilnej sytuacji zawodowej i materialnej, i to mimo rozpadu jej małżeństwa. Autorka opisuje swój udział w odbudowie kraju z wojennych zniszczeń, a także w rozwoju szkolnictwa i opieki nad młodzieżą.

\section{The diary of Helena Wróblewska - resident of the Western Territories}

Abstract: The diary was written by the teacher Helena Wróblewska, who came to Western Pomerania from the Eastern Borderlands of the Second Polish Republic. She received her education in post-war Poland and was first employed in office work, and then, after completing her education, fulfilled her dream by beginning to work as a teacher. Her story illustrates the societal progress and the steady and systematic work of a woman who recorded her memories from the perspective of a person with a stable professional and material situation, despite the collapse of her marriage. The author describes her own part in the reconstruction of the country after the destruction inflicted by the war, as well as in the development of the school system and care for the young.

Słowa kluczowe: Ziemie Zachodnie i Północne, Pomorze Zachodnie, ruchliwość społeczna, system edukacji

Key words: Western and Northern Territories, Western Pomerania, social movement, education system 